\title{
A COMPLICATED GRIEF INTERVENTION MODEL
}

Authors:

Cornelia M. Drenth

Alida G. Herbst ${ }^{2}$

Herman Strydom ${ }^{2}$

\section{Affiliations:}

${ }^{1}$ Hospice Palliative Care Association, Northwest Hospices, South Africa

${ }^{2}$ School for Psychosocial Behavioural Sciences, North-West University, Potchefstroom campus, South Africa

\section{Correspondence to:}

Alida Herbst

email:

alida.herbst@nwu.ac.za

\section{Postal address:}

Internal Box 184, North-

West University, Private Bag X6001, Potchefstroom

2520, South Africa

\section{Keywords:}

complicated grief

complicated grief

intervention model

(CGIM); Dual Process

Model (DPM); grief; Task-

Centred approach

\section{Dates:}

Received: 23 Jan. 2009

Accepted: 24 Mar. 2010

Published: 29 July 2010

How to cite this article: Drenth, C., Herbst, A.G \& Strydom, H., 2010,

'A complicated grief intervention model', Health SA Gesondheid 15(1), Art. \#415, 8 pages. DOI: 10.4102/hsag.v15i1.415

This article is available at:

http:/ / www.hsag.co.za

C 2010. The Authors. Licensee: OpenJournals Publishing. This work is licensed under the Creative Commons Attribution License.

\section{ABSTRACT}

Complicated grief refers to a prolonged state of grief and indicates the inability of the client to incorporate the death into his or her life. Few social workers in South Africa assess the possibility of complicated grief as a contributing factor to impaired social functioning. This can be as a result of limited knowledge, ignorance and/or insufficient skills on the part of the social worker to assess and identify complicated grief. In this article, the researchers tabulate some of the models and approaches to bereavement and discusses its applicability to complicated grief. Specific attention is given to the Dual Process Model (Stroebe \& Schut 1999) and the Task-Centred approach (a social work approach to therapy) in an attempt to develop a model for complicated grief intervention. This article furthermore proposes the Complicated Grief Intervention Model through the integration of the Dual Process Model and the Task-Centred approach while drawing on intervention techniques from other therapeutic approaches.

\section{OPSOMMING}

Gekompliseerde rou verwys na 'n verlengde staat van rou en impliseer 'n onvermoë by die klient om die dood van 'n geliefde in sy/haar lewe te integreer. Gekompliseerde rou word deur min maatskaplike werkers as bydraende faktor tot verlaagde maatskaplike funksionering geassesseer. Dit kan toegeskryf word aan beperkte kennis, ignorering van/of ontoereikende vaardighede by die maatskaplike werker in die identifisering en assessering van gekompliseerde rou. Die outeurs tabuleer sommige van die rouberadingsmodelle en -benaderings in hierdie artikel en bespreek die toepaslikheid daarvan op gekompliseerde rou. Spesifieke aandag word aan die Tweeledige Prosesmodel (Dual Process Model) (Stroebe \& Schut 1999) verleen, asook aan die taakgesentreerde benadering ('n maatskaplike werkbenadering) in 'n poging om ' $n$ model te ontwikkel vir gekompliseerde rou intervensie. Die artikel beveel aan dat die Gekompliseerde Rou Intervensie Model (GRIM) deur middel van die integrasie van die Tweeledige Prosesmodel en die taakgesentreerde maatskaplike werkbenadering aangebied word, terwyl intervensietegnieke van verskeie terapeutiese benaderings benut word.

\section{INTRODUCTION}

Grief is an experience felt all over the world by people who have lost a loved one through death. The manner in which the grieving takes place may differ from culture to culture. South Africa is no exception to the rule and the diversity of South African cultures is displayed in the grieving process (Bopapae 1995; Elion \& Strieman 2001; Hosking et al. 2000; Lydall 2004; Mdleleni-Bookholane 2003; Opperman 2004). Grief can, however, become complicated (Prigerson et al. 1995; Stroebe et al. 2001; Worden 1991) and can lead to impaired social functioning, which is of concern for the social worker.

Distinctions between normal and complicated grief are not easy to make. The setting of a cut-off point between normal and complicated grief is hampered by factors such as culture, religion, personality, age, society, mode of death, relationship with the deceased and many more. It is also not easy to differentiate between complicated grief and other related disorders such as depression, anxiety disorders and posttraumatic stress disorder (Worden 1991:75). The following definitions of terms directed this study:

- Grief is a normal process that occurs after the loss of a loved one and refers to the emotional distress associated with that loss. Grief is an individual process influenced by the relationship and the person's perception of the loss (Keene Reder 2003; Rosenblatt 1993; Zhang, El-Jawahri \& Prigerson 2006). Grief thus refers to the physical, emotional, cognitive, spiritual and social experiences of the loss.

- Complicated grief, traumatic grief, pathological grief and prolonged grief are used interchangeably in the literature. In this study, the concept of complicated grief is used. Complicated grief refers to a prolonged state of grief and indicates an inability of the client to integrate the death into his or her life. Complicated grief is characterised by a constant yearning and searching for the deceased, consistent thoughts of the deceased and intense and painful emotions. The intensity of the grief is prohibiting the client to regain the pre-loss state (or as close as possible to the pre-loss state) of social functioning (Keene Reder 2003; Kristjanson et al. 2006; Prigerson et al. 1995; Schut et al. 2001). According to Worden (1991:53), people fail to grieve due to the following: relational, circumstantial, historical, personality and social factors. The existence of complicated grief is also reflected in the increased interest of psychiatrists to include complicated grief as a pathological form of grief in the Diagnostic and Statistical Manual of Mental Disorders (DSM) (Shear \& Smith-Caroff 2002:1). At this stage the DSM-IV-TR includes a diagnosis of bereavement-related major depression if symptoms still exist two months after the loss (American Psychiatric Association 2000:684).

- Intervention refers to the social-work methods and strategies used by the social worker in a structured manner to enable the client to achieve the identified goals and objectives (Levine 2002:829).

Few social workers in South Africa assess the possibility of complicated grief as a contributing factor to impaired social functioning. This may be attributed to the following factors as were observed by the authors of this article: 
- the complicated grief knowledge base of social workers is limited

- social workers are ignorant of the impact of complicated grief on the social functioning of an individual

- social workers do not trust their own emotions when dealing with complicated grief

- social workers do not have sufficient skills to intervene when complicated grief is indicated.

The matters mentioned in the previous paragraph give rise to ethical and effective practice in social work. If social workers do not include the impact of the death of a loved one during assessment, how ethical and effective is the service? The authors are of opinion that a Complicated Grief Intervention Model (CGIM) will add to a better understanding of the client and that it will also enhance ethical and effective social-work practice in South Africa, specifically when one considers the impact of multiple losses (AIDS), socially unspeakable deaths (suicide) and crime-related deaths.

This article is a discussion of the CGIM as part of a dissertation on complicated grief intervention in the South African context

\section{PURPOSE OF THE STUDY}

This article aims at giving a condensed literature review on the most significant bereavement models/approaches. The article furthermore proposes a CGIM through the integration of The Dual Process Model of Coping with Bereavement (DPM) of Stroebe and Schut (1999) and the Task-Centred approach while drawing on intervention techniques from other models of therapy. The objective for this article is to propose a complicated grief intervention model for social workers and other professionals working in the field of loss and bereavement.

\section{CURRENT THEORETICAL PERSPECTIVES}

The following theoretical frameworks shaped the development of the CGIM:

- models of bereavement (Fleming \& Robinson 2001; Kristjanson et al. 2006; Lightbody 2005; Martin \& Doka 2000; Parkes 2001; Silvermann \& Klass 1996; Stroebe \& Schut 1999; Stroebe 2002; Worden 1991)

- DPM (Matthews \& Marwit 2004; Shaver \& Tancredy 2001; Stroebe \& Schut 1999; Stroebe \& Schut 2001; Zhang et al. 2006)

- Task-Centred approach (Doel 2006; Eaton \& Roberts 2002; Ligon 2002; Milner \& O’Byrne 1998; Reid \& Fortune 2002; Watson \& West 2006).

Recent research on grief in South Africa by authors such as Bopape (1995), Elion and Strieman (2001), Hosking et al. (2000), Lydall (2004), Mdleleni-Bookholane (2003) and Opperman (2004) also added to the theoretical framework of this study.

Kristjanson et al. (2006:72) contend that most bereavement services to date have been undertaken in a trial-and-error manner, while Bouton (1996:5) recommends the development of bereavement programmes to allow service providers to tailor services. It is with this recommendation in mind and the authors' own interests that the CGIM was developed.

\section{PROBLEM STATEMENT AND RESEARCH}

$$
\text { OBJECTIVES }
$$

Various bereavement intervention programmes were developed in the final quarter of the twentieth century ranging from bereavement self-help groups to therapy for people who experienced complicated grief. Several authors have made the statement that some grief intervention efficacy studies turned out to be disappointing and negative (Jordan \& Niemeyer 2003:765; Schut et al. 2001:705). Jordan and Niemeyer (2003:767-
770) refer to studies done by Allumbach and Hoyt (1999), Kato and Mann (1999), as well as Niemeyer (2003). Allumbach and Hoyt (1999) ascribe the low effect of bereavement intervention to the following: a general ineffectiveness of grief counselling, the low statistical power of many of the bereavement studies, or one or more variables that mask the real effects of the intervention. Kato and Mann (1999) give the following reasons for the disappointing effect: interventions for the bereaved are simply not helpful, they are not powerful enough (too few sessions) and the positive effects are masked by methodological issues (Jordan \& Niemeyer 2003:768). The perceived lack of effective complicated grief intervention programmes resulted in the following research objectives: (1) to explore existing literature and research on complicated grief and (2) to construct a CGIM.

\section{MOTIVATION FOR THE STUDY}

There are rural areas in South Africa where adult life-expectancy is low and infant mortality is high. Epidemics such as AIDS are wiping out large numbers of people (UNAIDS 2006) in both rural and urban areas. The number of adult deaths in South Africa increased by $62 \%$ over a period of 5 years from 272221 in 1997 to 441029 in 2002 (Statistics South Africa 2005:9). Prigerson (2005:10) found that approximately $10 \%-20 \%$ of people who have lost a loved one might be susceptible to complicated grief. This means that at least 52923 individuals (conservatively estimated at one bereaved person per deceased) might have experienced complicated grief in South Africa during 2002.

Social workers in South Africa are mostly influenced by Western models of grief and bereavement, such as Kübler-Ross' five stages of loss model, Worden's tasks of grief and Schneider's model of transformative grief (Watson et al. 2005: 750-751), while the risk-factors for complicated grief and cultural differences in South Africa may call for African-specific models. South African literature on complicated grief is limited, but recent research by South Africans includes: grief amongst Black, African learners (Mdleleni-Bookholane 2004), parental bereavement (Lydall 2004; Strydom \& Fourie 1998), the influence of context on complicated grief (Opperman 2004) and a South African perspective on cultural attitudes towards death and dying (Elion \& Strieman 2001; Hosking et al. 2000). The development of a CGIM has long been the interest of the authors. A thorough search for a CGIM in the South African literature revealed no such model. This urged the authors to seek an answer for the following research question: how can the social worker be empowered to assist a client who experiences complicated grief?

\section{RESEARCH METHOD AND DESIGN}

\section{Research approach}

This study was planned from the intervention research model (Creswell 2003:157-159; De Vos 2005:396; Fouché 2005:109) and consisted of two phases: (1) the exploratory phase, where a thorough literature study was done to examine the existing complicated grief intervention models with the aim of constructing a new model and (2) the intervention phase, where the suggested model was implemented and comparisons drawn between the objectives and outcomes of the intervention programme (Fouché \& De Vos 2005:147). The research design used was at exploratory and explanatory level (Grinnell \& Williams 1990:139-140; Mitchell \& Jolie 2001:518-519; Monette, Sullivan \& DeJong 2002:4). This article reports only on the literature study and the suggested complicated grief model.

\section{Research method}

This article focuses on an in-depth literature study and the building of a new model. Literature on complicated grief in social work is limited and it was necessary to access literature from other disciplines such as psychology, nursing, theology and anthropology. The books which were utilised included theses on 
TABLE 1

Models of Bereavement and applicability to complicated grief

\begin{tabular}{|c|c|}
\hline Models/Perspectives & Components \\
\hline \multicolumn{2}{|c|}{ Psycho-analytic / grief work } \\
\hline \multirow[t]{3}{*}{ Freud } & $\begin{array}{l}\text { Emphasises the necessity to break } \\
\text { attachment bond. }\end{array}$ \\
\hline & $\begin{array}{l}\text { Never tested his research with regards } \\
\text { to bereavement. }\end{array}$ \\
\hline & $\begin{array}{l}\text { Necessary to include reality of death to } \\
\text { avoid complication of death awarness. }\end{array}$ \\
\hline \multicolumn{2}{|l|}{ Stages } \\
\hline Lindman ( 3 stages) & $\begin{array}{l}\text { Shock and disbelief } \\
\text { Preoccupation with image of } \\
\text { deceased } \\
\text { Reenters daily life }\end{array}$ \\
\hline Kübler-Ross (5 stages) & $\begin{array}{l}\text { Shock and denial } \\
\text { Anger } \\
\text { Bargaining } \\
\text { Depression } \\
\text { Acceptance }\end{array}$ \\
\hline \multicolumn{2}{|l|}{ Phases } \\
\hline \multirow[t]{3}{*}{ Bowlby (3 phases) } & $\begin{array}{l}\text { Grief is a psychological process which } \\
\text { leads to relinquishing the deceased. }\end{array}$ \\
\hline & $\begin{array}{l}\text { Describes phases to compensate for } \\
\text { limitations of stages theories: }\end{array}$ \\
\hline & $\begin{array}{l}\text { - Numbness } \\
\text { Disbelief and trying to reverse } \\
\text { the outcome } \\
\text { - Disorganisation and } \\
\text { reorganisation }\end{array}$ \\
\hline \multirow[t]{12}{*}{ Rando (3 phases) } & $\begin{array}{l}\text { Introduced early attachment patterns } \\
\text { and adult attachment styles. }\end{array}$ \\
\hline & $\begin{array}{l}\text { Attachment theory works on the } \\
\text { principle of the child's attachment to } \\
\text { the mother. }\end{array}$ \\
\hline & Identifies 3 phases: \\
\hline & - Avoidance phase \\
\hline & Recognise the loss \\
\hline & - Confrontation phase \\
\hline & -React to the separation \\
\hline & $\begin{array}{l}\text { Recollect and re-experience the } \\
\text { deceased and the relationship }\end{array}$ \\
\hline & $\begin{array}{l}\text { Relinquish the old attachment to } \\
\text { the deceased and the old } \\
\text { assumptive world }\end{array}$ \\
\hline & - Accommodation phase \\
\hline & $\begin{array}{l}\text {-Re-adjust to new world without } f \\
\text { forgetting the old }\end{array}$ \\
\hline & -Re-invest in new relationships \\
\hline
\end{tabular}

Task model

Worden (4 tasks)

Martin \& Doka (added a 5th task)

Dual Process Model

Stroebe \& Schut Critique

Applicability to complicated grief

Absence of empirical evidence is questioning its effectiveness.

This model perceives that the absence of affect constitutes pathology.

The stages theory implies that individuals grieve in the same manner.

It gives the impression that grieving is an orderly process.

It only focuses on psychological reactions, neglecting the physical, spiritual and social components.

Absence of affect during the grieving process is perceived as pathological.

The uniqueness of individual grieving patterns does not come clear.

Limited referral to physical, spiritual and social contex of grieving.

Concentrates on the display of emotions and does not include the individual who grieves without displaying emotions.

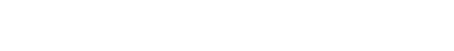

Limited applicability

This perspective has limited significance in the sense that it only provides a basic background to some of the emotions attached to the normal process of grieving. It does not include the possibility that individuals can grieve without displaying emotion. Complicated grief is not addressed as such in the stages theories, although Lindeman was one of the first people to note deviation from 'normal' gire first people to note deviations from 'normal' grief, but fail to recognise the importance of chronic/
complicated grief.
Limited significance in that it is more focused on emotions rather than including all aspects affected by the death of a significant person, such as physical; spiritual and social implications.

Of greater significance is the introduction of attachment patterns and attachment styles. Of relevance is the impact of childhood bereavement on attachment patterns or how these patterns impact on end-of-relationship adjustment.

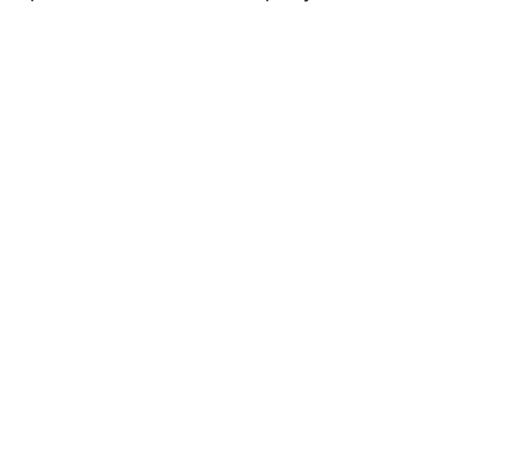

Worden recognises that delayed or disenfranchised grief can lead to complicated or chronic grief.

Complicated grief is identified when a person is stuck and experiences difficulty to move on to the next task - therapist relies on experience to ascertain whether client is experiencing complicated grief.

Doka assists in the afore-mentioned process with an explanation of grief patterns.
Very applicable when intensity and duration of adjustment are included. The tasks add a framework for complicated grief intervention in explaining the process to the client and in developing an understanding of affect, cognitions, spirituality and social adjustment.

Significance lies in distinguishing between different patterns of grief to ensure an effective therapeutic intervention programme for each individual. The Grief Pattern Inventory (Martin \& Doka 2000 167) is a useful instrument. 
the identified topic. The main focus was, however, on accessing recent journal articles and research publications. A systematic library search was conducted during this study by utilising the following databases: NRF Nexus database system and research networking, Social Sciences Citation Index, Social Sciences Index, Institute for scientific information and EBSCO host. The literature study was conducted throughout the research study.

In addition to database searches for published articles, websites were searched for additional resources. However, complicated grief was very briefly discussed in only a few of these websites. It was found that complicated grief intervention programmes are even less discussed in all forms of literature. Kristjanson et al. (2006:14) refer to the fact that they could not find resource kits specifically aimed at complicated grief, thus supporting the researchers' inability to find reliable complicated grief intervention programmes.

\section{Philosophical analysis}

It is common knowledge that most deaths occur in the age group of 65 and older in the majority of communities. Zhang, El-Jawahri and Prigerson (2006:1188) are of opinion that the frequent experience of the death of friends and relatives as they grow older gives rise to the tendency among clinicians to 'normalize and potentially dismiss the distress and disruption evoked by bereavement'. Zhang et al. (2006:1188) furthermore refer to the fact that research has proven that the death of a loved one is among the most stressful experiences in life. The same authors accentuate the need for social workers to be able to distinguish between complicated and uncomplicated grief reactions, identify risk factors for complicated grief and take informed actions to prevent and intervene in order to minimise complications in the grieving process.

\section{Literature review}

Literature on some of the most important models/perspectives is summarised in Table 1 and reflects the applicability of each model/approach to complicated grief. The underlying value of the different approaches lies in the integration of knowledge regarding all aspects of grief, as well as in forming a platform from where complicated grief can be explored.

From the summary in Table 1, it is clear that literature on bereavement/grief models ranges from stages, phases, grief work, tasks, attachment, continuing bonds to oscillation between loss-orientation and restoration-orientation (Fleming \& Robinson 2001; Kristjanson et al. 2006; Lightbody 2005; Martin \& Doka 2000; Parkes 2001; Silverman \& Klass 1996; Stroebe 2002; Stroebe \& Schut 1999; Worden 1991). Recent research on grief and bereavement in South Africa was done by Bopape (1995), Mdleleni-Bookholane (2003), and Strydom and Fourie (1998), while Opperman (2004) researched the influence of context on complicated grief. Models and approaches on grief include the notion that the grief process includes a series of stages and that normal grief will only prevail once the grief process is completed (Bowlby 1980; Lindemann 1944). Completion of the grief process requires that an attachment or bond be relinquished and new attachments be formed (Bowlby 1980; Lindemann 1944). Klass, Silverman and Nickman (1996) are of opinion that it is not necessary to discontinue bonds with the deceased in completing the grief process, but that altering and maintaining the bond with the deceased can be beneficial for the bereaved.

The DPM describes ways in which people adapt to their grief. The grieving individual occasionally confronts and sometimes avoids the cognitive and emotional processes (Matthews \& Marwit 2004:853). The mentioned model constitutes that a bereaved person's emotions and behaviour oscillate between two distinct domains - loss-orientation and restorationorientation, thus meaning that a person deals with two different types of stressors in the grieving process. The first domain (stressor), loss-orientation, refers to activities that deal with separation from the deceased and includes crying, missing, yearning, remembering as well as other activities dealing with the loss itself. The person thus concentrates on the loss and attempts to process the loss experienced. The grief work concept (Worden 1991) falls within this area of the model. Bowlby's attachment theory regarding the nature of the lost relationship and the value of grief work (Horowitz et al. 1997; Worden 1991) is consistent with the loss-orientation concept as described in the DPM. Positive and negative emotions are experienced, from happy memories, to painful longing. Restoration-orientation does not refer to the outcome, but to what needs to be dealt with and how to deal with it. It emphasises the secondary stressors of bereavement. It also refers to adjustment to the loss in all areas of social functioning, for example social isolation and loneliness and role changes (e.g. from 'spouse' to 'widow'), all with the accompanied emotional reactions. In this domain, the mourner is forced by circumstances to 'carry on with life', while he or she actually wishes to stop the world, get off for a while and then jump on again when he or she is ready to face a life without the deceased.

\section{Conceptual analysis}

The theoretical foundation of the CGIM is based on an eclectic and integrative approach. Therapeutic models of practice, such as cognitive-behavioural, narrative and solution-focused models form the basis of intervention in the proposed CGIM. The CGIM is not aimed at the social worker's intellectual ability, but at the skill to work with the client to restore social functioning after the loss of a loved one. The CGIM is also aimed at releasing a client's own skills and capabilities to achieve the desired outcome.

The authors share the view of Watson and West (2006:9) that 'in an occupation such as social work, the process (what we do) is as important as the outcome (what is achieved).' The desired outcome of intervention might not be achieved if the effect of complicated grief on the social functioning of the grieving person is ignored or denied. The CGIM draws on intervention techniques from other approaches and theories such as the cognitive-behavioural, solution-focused and narrative theories. A brief description of these approaches is necessary for clarification.

\section{Cognitive-behavioural therapy}

Cognitive-behavioural therapy refers to intervention that targets the observable and changeable behaviour of a client (Brown 2006; Cigno 2006:186; Vonk \& Early 2002:116; Watson \& West 2006:82). Assessment is crucial in behavioural social work as it takes the manifestation of behaviour and what needs to be changed into account. Frequency and intensity of behaviour leads to clarity of information of what is happening and how often. Client logs or diaries are examples of how the frequency and intensity can be measured. Once the baseline is established through the measurement, then intervention can be planned. Intervention is aimed at behaviour, as well as at thoughts and feelings and the impact thereof on behaviour. Cognitions such as 'I miss her every day', and 'I am a single person in a "couple" society', are but two bereavement-related examples with which the social worker is often confronted. Matthews and Marwit (2004:859) are of opinion that cognitive-behavioural therapy might not be enough to address grief. It is therefore necessary to integrate different practice models in assisting the client to incorporate the loss of a loved one into his or her life.

\section{Narrative Therapy}

Narrative therapy aims at assisting the client in deconstructing the stories of their lives by firstly understanding it and then broadening and challenging them by creating new realities (Kelley 2002:121; Reyneke 2004:130). Thomas (2000:301) is of opinion that the self-conception, relationships and life experiences become meaningful once the client is allowed to tell his or her story. Key concepts of narrative therapy are: externalising the problem, problem-saturated stories, mapping the problem's domain, unique outcomes, and spreading the news (Kelley 2002:122). Narrative therapy plays a role in 
complicated grief intervention. Bowman (1999:179) excellently describes the use of narrative therapy as follows: 'The creation of a new identity after loss can require grieving who or what we were - an earlier story - as a prerequisite for the new or adapted story'.

\section{Solution-focused therapy}

The aim of solution-focused therapy (SFT) is to identify solutions to problems (Cooper \& Lesser 2002:193; De Jong 2002:112) by utilising existing coping mechanisms and skills to resolve new challenges (Watson \& West 2006:53). The conversations in solution-focused therapy is similar to those of narrative therapy in that the focus is on what the client wishes to change and what is necessary to bring about the change. Research findings by De Jong (2002:112) indicates that clients with clear visions of what they wished were different made more progress than those who could not identify what must change. Solution-focused therapy assumes that the client is competent to co-construct goals and strategies and is the expert about his own life. It further construes that something must be done to effect change (De Jong 2002:113).

\section{Model building: The complicated grief intervention model}

The necessity for a complicated grief intervention model became evident in the authors' attempt to find such a model with clear guidelines in South Africa. The proposed CGIM (Diagram 1) was developed from this need and must be regarded as a flexible and adaptable programme. The CGIM is developed to use the strengths and resources of the client and therefore holds the possibility to be implemented amongst different cultures, age groups and genders, which allows it to be of value in the diverse environment of South Africa. The purpose of the proposed CGIM is not to remove the pain of grief, but to enable the bereaved to incorporate the loss into their lives in whatever way feels right for them, thus making them equal partners with the social worker in the intervention process. The CGIM has the DPM (Stroebe \& Schut 1999) and the Task-Centred social work approach (Doel 2006; Ligon 2002; Reid \& Fortune 2002; Watson \& West 2006) as a theoretical framework. The CGIM focuses on the completion of loss-related tasks, as well as the completion of tasks related to the restoration after death. The CGIM is a three-step process: assessment, intervention and evaluation/ termination.

The CGIM is specifically developed for complicated grief intervention. The CGIM relies on the systematic collection and verification of data as proposed in the Task-Centred social work approach (Doel 2006; Milner \& O’Byrne 1998; Reid \& Fortune 2002; Watson \& West 2006). The goal of the intervention through the CGIM is to enable the client to incorporate the loss of a significant other into his or her live in whatever way feels right for him or her, taking into account the individual's grief pattern, culture, background and relationship to the deceased. The purpose of this model (CGIM) is to make small, effective, measurable changes within the ambit of complicated grief. Ligon (2002:98) and Martin and Doka (2000:133) are of opinion that carefully developed goals and objectives will create a positive effect in the sense that the client is able to experience initial success. The stance of the social worker is to believe that things can change and to work with what the client brings, such as past successes, survival skills, and life wisdom (Ligon 2002:97).

The CGIM has a time-limited approach. Up until the 1970s, social workers concentrated on psychosocial casework, after which a gradual movement towards more short-term methods

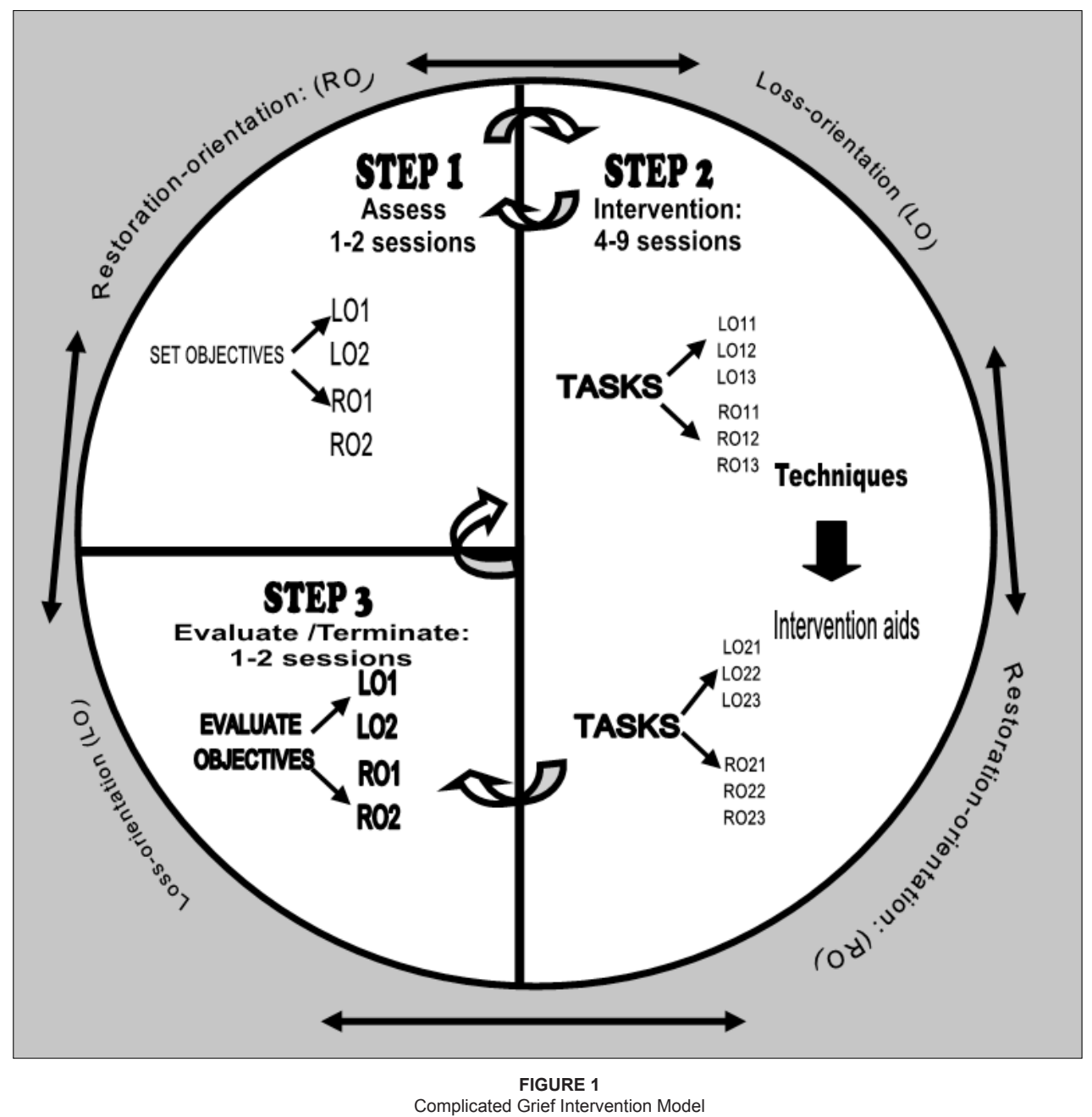


of intervention were identified. The emphasis shifted from the unjust and unequal nature of society to locating the source of the problem and finding the solution in the client (Milner \& O'Byrne 1998:131; Watson \& West 2006:52). Intervention became more solution-focused than problem-focused. The Task-Centred approach was initiated and created specifically for social work (Doel 2006:193; Watson \& West 2006:73). It has the added advantage that it is an effective approach to use within the diverse South African culture.

The CGIM is set out in Diagram 1 and will be discussed in detail in the following paragraphs.

The CGIM consists of three steps: Assessment, intervention and evaluation/termination.

\section{Step 1: Assessment}

Assessment is a continuous process and starts with the first interview. The authors agree with Morris (2006:8) that the personal interview is the most reliable method of data collection - you can see the client, you can make a non-verbal assessment of the circumstances and it is a sensitive way of making contact.

Step 1 of the CGIM takes up to two sessions and is aimed at a thorough assessment of the client's needs by listening to the client's story. The story of each client is unique and the social worker has the opportunity to reflect to cultural norms and processes during these sessions. This is especially of significance in South Africa with its diverse cultural groups and differences in death and dying values. The social worker and the client come to a mutual agreement on the targets to be met and set the objectives to reach the goal. A partnership between the worker and the client is established and the client chooses the tasks which he or she is ready to encounter. The client is the main agent of change in this model and the CGIM allows the client to visualise the outcome within realistic parameters. Worden (1991:75-77) assists the social worker in mentioning twelve specific clues to identify complicated grief:

- difficulty in mentioning the deceased without expressing intense grief

- a relatively minor event triggers an intense grief reaction

- the bereaved finds it difficult to part with the material belongings of the deceased

- themes of loss continuously come up in conversation

- the bereaved manifests the same physical symptoms as the deceased

- $\quad$ radical life style changes (Prigerson 2005:12)

- persistent guilt and a lowered self-esteem, coupled with depression, prevail

- the bereaved tends to imitate the deceased

- suicidal ideation

- unaccountable sadness at certain times of the year

- the bereaved experiences phobias about illness and death

- the bereaved avoids death related rituals and activities.

The abovementioned clues are useful for the social worker in the assessment of the client and his tendered problem.

It is of importance that the social worker not only assess the emotional side of bereavement (loss-orientation), but includes the practical issues and demands (restoration-orientation) of grief, such as funeral arrangements, estate management and returning to work. The social worker explores whether the client knows, or has an idea where, the problem lies. The client tells his story with as little interruption as possible. By listening to the client's story, the social worker acknowledges and validates the grief experience of the client. The social worker explores the feelings and thought patterns the client experienced prior, during and after the death. The story is tape-recorded (with the consent of the client) to enable both the client and the social worker to reflect back on events, emotions and any other aspects which may be of therapeutic value. Retelling the story often decreases the grief intensity and enables the client to acknowledge aspects which he or she did not pay attention to previously. This includes successes since the death occurred.
During the assessment, the social worker searches for information on causes and solutions in the present situation, but does not negate past experiences (Milner \& O'Byrne 1998:134). The social worker identifies the factors which are aimed at resolving complicated grief. It involves the completion of achievable and mutually agreed tasks or solution-focused activities. Martin and Doka (2000:133) confirm the importance for grievers to clarify goals and objectives. The social worker guides the client to set objectives in order to reach the goal. Objectives are divided into objectives related to loss-orientation (LO) and objectives related to restoration-orientation ( $\mathrm{RO})$. As many objectives as necessary are identified, recorded and prioritised.

For purpose of explaining the CGIM, loss-orientation is abbreviated to LO while restoration-orientation is abbreviated to RO. LO-1 refers to the loss orientation objective with the highest priority, while LO-2 refers to the loss orientation objective with the second highest priority. RO-1 refers to the restoration orientation with the highest priority while $\mathrm{RO}-2$ refers to the restoration orientation objective with the second highest priority. An example of LO-1 can be: 'to stop crying every time I see his photo', and LO-2: 'to visit the graveyard.' An example of $\mathrm{RO}-1$ can be 'to attend the work end-year function as a widow', and RO-2: 'to exercise a hobby.'

\section{Step 2: Intervention}

Watson and West (2006:51) state that social workers often lack structured planning in their intervention. The intervention then becomes reactive and responds only to specific events or crises. The utilisation of the CGIM provides the opportunity to structure and plan the intervention (Ligon 2002:96; Watson \& West 2006:51). The social worker is allowed to use any interventions that may be effective to bring about change and which is ethical and relevant. The CGIM is a model of brief structured intervention. It starts where the client is, and works towards a solution-focused end. It gives the client a sense of control in the intervention process. Assessment information is shared with the client to ensure commitment and partnership and to develop his or her problem-solving skills. Watson and West (2006:75) are of opinion that dependency is reduced as the client is able to decide what can or cannot be achieved.

Step 2 is the phase where the objectives are prioritised and divided into tasks as part of the intervention. The Task-Centred social-work approach forms part of the theoretical framework of the CGIM and is an active approach in that tasks are negotiated and well planned, implemented and has a specific purpose (Ligon 2002:98; Milner \& O'Byrne 1998:134). The tasks are the means to an end, the stepping stones towards the ultimate goal. Tasks are more than just physical actions. It can be something such as a client log, cognitive reflections or mental lists. It is the role of the social worker to guide the client through setting realistic targets and to assist the client in breaking these down into achievable targets. Once the tasks are set, both parties enter into an agreement (which preferably needs to be in writing) in terms of who does what, when and why (Doel 2006:195). It is encouraged that the client be empowered to perform most of the tasks, either alone or with the assistance of the social worker. Doel $(2006: 195)$ states that the Task-Centred encounter should have the 'feel of a highly participative workshop'. The advantage of this is that the client gains confidence and improves his or her problem-solving skills.

If, for example, one of the objectives is to start thinking of exercising a hobby, the implementation plan involves the following tasks: determining what kind of hobby, locating a training facility, costs involved, dates of new enrolment, the first contact with strangers, etc. A good question for the social worker to ask the client at this stage is: 'What will you gain from this?' This question points out the benefits of success and affords the client the opportunity to set future goals. It is recommended that the tasks which stand the best chance of success be implemented first to allow the client to gain confidence in the intervention process through the experience of success. 
The social worker uses different kinds of questions relating to goal-formulation, exception-finding, scaling, coping and questions about 'what's better' during the conversation in establishing the intervention process and the 'working together' of the social worker and the client. Questions are aimed at the 'who', 'what', 'where' and 'how' of goal attainment (De Jong 2002:113-114; Cooper \& Lesser 2002:193).

The tasks for objective LO-1 (loss-orientation, objective 1) is numbered as follows:

- LO-1-1 refers to the first task of the first objective for loss orientation. If LO- 1 is 'to stop crying every time I see his photo', then LO-1-1 may be 'to look at the photo for 5 minutes per day'.

- LO-1-2 will then be the second task of objective 1 and can be described as: 'monitor your emotions when you look at the photo'. It is important to notice that different tasks can be executed at the same time.

The tasks for objective RO-1 (restoration-orientation, objective 1) is numbered as follows:

- RO-1-1 refers to the first task of the first objective for restoration-orientation. If RO-1 is 'to identify a new hobby', then RO-1-1 may be 'to identify the hobby'.

- RO-1-2 (second task of the first objective) may be 'to find someone who can teach me.'

Continuous assessment of the relevance of the objectives and tasks is an important aspect during intervention. Assessment allows the social worker and the client to evaluate the accomplishments and to assess the success of the tasks within different cultures, genders and language. The social worker assists the client in pointing out all possible obstacles in achieving success and in shaping plans to avoid these obstacles or in preparing to manage the obstacle. 'What if'-questions are an excellent way of identifying obstacles during the planning process, for example: 'What if I cannot get myself to look at the photo?'

\section{Step 3: Evaluation and termination}

Evaluating the outcomes of the CGIM is the main focus during evaluation and termination. The continuous assessment during step 2 will ensure that the client is aware of the nearing termination of service. The social worker enhances the cooperation of the client by reviewing the rationale (Hepworth, Rooney \& Larsen 2002:591). The purpose of evaluation is to assess the results achieved against the formulated objectives in Step 1. According to Hepworth et al. (2002:591), the outcomes, the process and the social worker should be included in the evaluation process. This should then be the focus of the social worker during this step for the CGIM to be credible.

Continuous assessment is done throughout intervention by evaluating objectives and tasks during each intervention session. In step 3, the social worker and the client evaluate the initial objectives and decide whether they were met. The process and also the professional performance of the social worker are assessed. It is during this session that successful solutionfocused strategies are identified and discussed. If the client is of opinion that some of the objectives were not met, the process can be extended and objectives and tasks reviewed. However, it is critical to decide what really can be accomplished by extending the service. The authors agree with Ligon (2002:104) who is of opinion that little progress by the 12th visit will not show more progress by the 20th visit.

\section{DISCUSSION AND CONCLUSION}

This article tabulates some of the most important models/ approaches to bereavement and proposes the CGIM in answer to the research question: 'How can social workers be empowered to assist the client with complicated grief?' The proposed CGIM was developed as a guideline for social workers in assisting clients who experience difficulty in adapting to the death of a loved one. The CGIM is based on the DPM developed by Stroebe and Schut (1999) and the Task-Centred approach which was specifically developed for social work. The CGIM is a time-limited intervention model and consists of three steps: assessment; intervention; and evaluation and termination. Lossorientation and restoration-orientation objectives are set while each objective is subsequently divided into manageable tasks. Objectives and tasks are evaluated and reviewed during each session and both the social worker and the client is actively involved in the process.

Although the proposed CGIM has not yet been scientifically tested, it has the potential to serve as a guideline for social workers working in the field of grief and bereavement. Further research on the utilisation of the CGIM in diverse cultural groups is necessary.

\section{REFERENCES}

Allumbach, D.L. \& Hoyt, W.T., 1999, 'Effectiveness of grief therapy: A meta-analysis', Journal of Counseling Psychology 46, 370-380.

American Psychiatric Association, 2000, Diagnostic and statistical manual of mental disorders, 4th edn., text rev., American Psychological Association, Washington, DC.

Bopape, M., 1995, 'The Bapedi framework of mourning and bereavement and its implications for the helping professions', Social Work 31(3), 262-266.

Bouton, B.L., 1996, 'The interdisciplinary bereavement team. Defining and directing appropriate bereavement care', The Hospice Journal 11(4), 15-24.

Bowlby, J., 1980, Attachment and loss. Loss: sadness and depression, vol. 3, Hogarth, London.

Bowman, T., 1999, 'Shattered dreams, resiliency, and hope. Restorying after loss', Journal of Personal and Interpersonal Loss 4, 179-193.

Brown, H.C., 2006, 'Counselling', in R. Adams, L. Dominelli \& M. Payne (eds.), Social work. Themes, issues and critical debates, pp. 139-148, Palgrave, London.

Cigno, K., 2006, 'Cognitive-behavioural practice', in R. Adams, L. Dominelli \& M. Payne (eds.), Social work. Themes, issues and critical debates, pp. 180-190, Palgrave, London.

Cooper, M.G. \& Lesser, J.G., 2002, Clinical social work practice. An integrated approach, Allyn \& Bacon, Boston.

Creswell, J.W., 2003, Research design. Qualitative, quantitative, and mixed methods approaches, 2nd edn., Sage Publications, Thousand Oaks.

De Jong, P., 2002, 'Solution-focused therapy', in A.R. Roberts \& G.J. Greene (eds.) Social workers' desk reference, pp. 112-116, University Press, Oxford.

De Vos, A.S., 2005, 'Intervention research', in A.S. de Vos, H. Strydom, C.B. Fouche \& C.S.L. Delport (eds.), Research at grass roots. For the social science and human service professions, pp. 394-418, Van Schaik, Pretoria.

Doel, M., 2006, 'Task-Centred work', in R. Adams, L. Dominelli \& M. Payne (eds.), Social work. Themes, issues and critical debates, pp. 191-199, Palgrave, London.

Eaton, Y.M. \& Roberts, A.R., 2002, 'Frontline crisis intervention: Step-by-step practice guidelines with case applications', in A.R. Roberts \& G.J. Greene (eds.), Social workers' desk reference, pp. 89-96, University Press, Oxford.

Elion, B. \& Strieman, M., 2001, Clued up on culture: A practical guide for all South Africans, One Life media CC, Cape Town.

Fleming, S. \& Robinson, P., 2001. 'Grief and cognitive-behavioral therapy. The reconstruction of meaning', in M.S. Stroebe, R.O. Hansson, W. Stroebe \& H. Schut (eds.), Handbook of bereavement research. Consequences, coping and care, pp. 647669, American Psychological Association, Washington, DC.

Fouché, C.B., 2005, 'Problem formulation', in A.S. de Vos, H. Strydom, C.B. Fouché \& C.S.L. Delport (eds.), Research at grass roots. For the social science and human service professions, pp. 104-113, Van Schaik, Pretoria.

Fouché, C.B. \& De Vos, A.S., 2005, 'Quantitative research designs' in A.S. de Vos, H. Strydom, C.B. Fouché \& C.S.L. Delport (eds.), Research at grass roots. For the social science and human service professions, pp. 137-149, Van Schaik, Pretoria. 
Grinnell, R.M. \& Williams, M., 1990, Research in social work. A primer, Peacock, Itasca, Il.

Hepworth, D.H., Rooney, R.H. \& Larsen J.A, 2002, Direct social work practice: Theory and skills, 6th edn., Brooks/Cole, Victoria.

Horowitz, M.J., Siegel, B., Holen, A., Bonanno, G., Milbrath, C \& Stinson, C., 1997, 'Diagnostic criteria for complicated grief disorders', American Journal of Psychiatry 154(7), 904-911.

Hosking, M., Whiting, G., Brathwate, C., Fox, P., Boshoff, A. \& Robbins, L., 2000, 'Cultural attitudes towards death and dying: A South African perspective', Palliative Medicine 14, 437-439.

Jordan, J.R. \& Niemeyer, R.A., 2003, 'Does grief counseling work?', Death studies 27, 765-786.

Kato, P.M. \& Mann, T., 1999, 'A synthesis of psychological intervention for the bereaved', Clinical Psychology Review 19, 275-296.

Keene Reder, E.A., 2003, 'Grief and bereavement' in J.F. O'Neill, P.A. Selwyn \& H. Schietinger (eds.), A clinical guide to supportive and palliative care for HIV/AIDS, pp. 329-347, Department of health and human services (HRSA), USA.

Kelley, P., 2002, 'Narrative Therapy', in A.R. Roberts \& G.J. Greene (eds.), Social workers' desk reference, pp. 121-124, Oxford University Press, USA.

Klass, D., Silverman, P.R. \& Nickman, S.L. (eds.), 1996, Continuing bonds, Taylor and Francis, Washington, DC.

Kristjanson, L., Lobb, E., Aoun, S. \& Monterosso, L., 2006, 'A systematic review of the literature on complicated grief', Department of health and ageing, Australian Government, viewed 02 September 2007, from http://www.dcita.gov.au/cca

Levine, E.R., 2002, 'Glossary', in A.R. Roberts \& G.J. Greene (eds.), Social workers' desk reference, pp. 829-849, Oxford University Press, USA.

Lightbody, T.K., 2005, 'Neonatal death: A grief intervention framework', Illness, crisis $\mathcal{E}$ loss 13(3), 191-200.

Ligon, J., 2002, 'Fundamentals of brief treatment principles and practice', in A.R. Roberts \& G.J. Greene (eds.), Social workers' desk reference, pp. 96-100, Oxford University Press, USA.

Lindemann, E., 1944, 'The symptomatology and management of acute grief', American Journal of Psychology 101, 141-148.

Lydall, A., 2004, Give sorrow words: The meaning of parental bereavement, D.Litt et Phil thesis, University of Johannesburg [Rand Afrikaans University].

Mattin, T.L. \& Doka, K.J., 2000, Men don't cry...women do. Transcending gender stereotypes of grief, Taylor \& Francis, Philadelphia.

Matthews, L.T. \& Marwit S.J., 2004, 'Complicated grief and the trend toward cognitive-behavioral therapy', Death Studies 28, 849-863.

Mdleleni-Bookholane, T.N., 2003, 'The development of an understanding of the concept of death by black African learners in a rural area', D.Litt.et.Phil Dissertation, University of Johannesburg [Rand Afrikaans University].

Milner, J \& O’Byrne, P., 1998, Assessment in social work, Palgrave Macmillan, Tokyo

Mitchell, M. \& Jolie, J. 2001, Research design explained, 4th edn. Harcourt College Publications, Fort Worth.

Monette, D.R., Sullivan, T.J. \& Dejong, C.R., 2002, Applied social research. Tool for the human services, 6th edn., Brooks/Cole, Victoria.

Morris, T., 2006, Social work research methods: four alternative paradigms, SAGE Publications, Thousand Oaks.

Opperman, B.C.D., 2004. 'The influence of context on complicated grief', D.Litt.et.Phil Dissertation, University of Johannesburg [Rand Afrikaans University].

Parkes, C.M., 2001, 'Introduction: Voncepts and issues in contemporary research on bereavement', in M.S. Stroebe, R.O. Hansson, W. Stroebe \& H. Schut (eds.), Handbook of bereavement research. Consequences, coping and care, pp. 3-22, American Psychological Association, Washington, DC.

Prigerson, H., 2005, 'Complicated grief: When the path of adjustment leads to a dead end', Healthcare counseling $\mathcal{E}$ psychotherapy Journal 5(3), 10-13.
Prigerson, H.G., Maciejewski, P.K., Reynolds, C.F. III., Bierhals, A.J., Newsom, J.T., Fasiczka, A. et al., 1995, 'Inventory of complicated grief: A scale to measure maladaptive symptoms of loss', Psychiatry Research 59(1-2), 65-79.

Reid, W.J. \& Fortune, A.E., 2002, 'The task-centered model' in A.R. Roberts \& G.J. Greene (eds.), Social workers' desk reference, pp. 101-104, Oxford University Press, USA.

Reyneke, R.P., 2004, 'Die benutting van narratiewe beginsels tydens gemeenkapsontwikkeling [The use of narrative principles during community development]', Social Work/ Maatskaplike Werk 40(2), 125-137.

Rosenblatt, P.C., 1993, 'Cross-cultural variation in the experience, expression, and understanding of grief', in D.P. Irish, K.F. Lindquist \& V.J. Nelsen (eds.), Ethnic variations in dying, death and grief : diversity in universality, pp. 13-19, Taylor and Francis, London.

Schut, H., Stroebe, M.S., van den Bout, J. \& Terheggen, M., 2001, 'The efficacy of bereavement interventions. Determining who benefits', in M.S. Stroebe, R.O. Hansson, W. Stroebe \& H. Schut (eds.), Handbook of bereavement research. Consequences, coping and care, pp. 705-737, American Psychological Association, Washington, DC.

Shaver, P.R. \& Tancredy, C.M., 2001, 'Emotion, attachment, and bereavement. A conceptual commentary', in M.S. Stroebe R.O. Hansson, W. Stroebe \& H. Schut (eds.), Handbook of bereavement research. Consequences, coping and care, pp. 63-88, American Psychological Association, Washington, DC.

Shear, M.K. \& Smith-Caroff, B.S., 2002, 'Traumatic loss and the syndrome of complicated grief', PTSD Research Quarterly 13(1), 1-8.

Silverman, P.R. \& Klass, D., 1996, 'Introduction. What's the problem?' in D. Klass, P.R. Silverman \& S.L. Nickman (eds.), Continuing bonds, pp. 3-27, Taylor \& Francis, New York.

Statistics South Africa, 2005, Mortality and causes of death in South Africa, 1997-2003, Government Press, Pretoria.

Stroebe, M.S., 2002, 'Paving the way. From early attachment theory to contemporary bereavement research', Mortality 7(2), 127-138.

Stroebe, M.S., Hansson, R.O., Stroebe, W. \& Schut, H., 2001 'Introduction: Concepts and issues in contemporary research on bereavement', in M.S. Stroebe, R.O. Hansson, W. Stroebe \& H. Schut (eds.), Handbook of bereavement research. Consequences, coping and care, pp 285-300, American Psychological Association, Washington, DC.

Stroebe, M. \& Schut, H., 1999, 'The dual process model of coping with bereavement. Rationale and description', Death Studies 23, 197-224

Stroebe, M.S. \& Schut, H., 2001, 'Models of coping with bereavement. A review', in M.S. Stroebe, R.O. Hansson, W. Stroebe \& H. Schut (eds.), Handbook of bereavement research. Consequences, coping and care, pp. 375-403, American Psychological Association, Washington, DC.

Strydom, H. \& Fourie, J., 1998, 'The content evaluation of a bereavement counseling programme for parents after the death of a child', Social Work 34 (4), 389-404.

Thomas, N.D., 2000, 'Generalist practice with people of color', in J. Poulin and contributors, Collaborative social work. Strengthbased generalist practice, pp. 295-325, Brooks/Cole, Belmont.

UNAIDS, 2006, Report on the global AIDS epidemic, UNAIDS, Geneva.

Vonk, M.E. \& Early, T.J., 2002, 'Cognitive-behavioral therapy', in A.R. Roberts \& G.J. Greene (eds.), Social workers' desk reference, pp. 116-120, University Press, Oxford.

Watson, M.S., Lucas, C.F., Hoy, A.M. \& Back, I.N., 2005, Oxford handbook of palliative care, Oxford University Press, USA.

Watson, D. \& West, J., 2006, Social work process and practice. Approaches, knowledge and skill, Palgrave Macmillan, Tokyo.

Worden, J.W., 1991, Grief counseling and grief therapy. A handbook for the mental health practitioner, 2nd edn., Routledge, London.

Zhang, B., El-Jawahri, A. \& Prigerson, H.G., 2006, 'Update on bereavement research. Evidence-based guidelines for the diagnosis and treatment of complicated bereavement', Journal of Palliative Medicine 9(5), 1188-1203. 